\title{
THE OPERATIONAL READINESS FOR ANTI SUBMARINE INDONESIAN NAVAL BY USING ANTI SUBMARINE HELICOPTER
}

\author{
Muksin $^{1}$, Udi Subhakti ${ }^{2}$, Sutrisno $^{3}$, Sunarta $^{4}$ \\ 1,3,4 Indonesian Naval Technology College, STTAL, Surabaya, Indonesia \\ 2Industrial Engineering Department, Institut Teknologi Sepuluh Nopember, Surabaya, Indonesia
}

\begin{abstract}
Some of the Indonesian naval effort to see and protect the Indonesian territory is by using Helicopter sea patrol. In the other side, submarines are the most strategic weapons in the world that can provide a deterrence effect which has a very significant impact on the maritime powers of the countries operating them in the era of generation 4.0 war. Operational readiness is very important, there are readiness in building operational readiness for naval defense through budget fulfillment, utilization of existing resources, procurement and naval modernization by paying attention to Life Cycle Cost, and interoperability while still paying attention to paradigm shifts in naval capability. So, the combat readiness is the condition of the Indonesian Navy's defense equipment and its constituent units, resources and personnel, weapon systems and other military technology equipment in a condition that is ready to carry out military operations in an unspecified time, or function consistent with the purpose for which the defense equipment is organized or designed, the management of resources and training personnel in preparation for combat in the face of the threat of modern warfare in a state of constant combat readiness. At this time, training in Anti-Submarine Warfare conducted by Indonesian Navy's Helicopter is still limited to carrying out flight procedures, communication procedures with the KRI and the command line, because Helicopters have sensors, weapons and command that need to be upgraded and The personnel also have underwater warfare capabilities that need to be upgraded, so there needs to be an increase in the capability of the helicopter and human resources. Technometry will be used to calculate the Heli's current readiness level.
\end{abstract}

Keywords: Submarine, Anti Submarine Helicopter and operational readiness.

\section{INTRODUCTION}

The Improvement of strategic issues influenting some country to decide the kind of the defend way to protect their territory. And it can determine some country in determining national political policies, including defense and security. Currently submarines are the most strategic weapons in the world that can provide a deterrence effect which has a very significant impact on the maritime powers of the countries operating them in the era of generation 4.0 war. The pattern of relevant combat tactics needs to be applied in Indonesian Archipelago Waters when faced with areas of vulnerability and choke points, geographical constellations and sea contours.

Advances in weaponry technology have allowed aircraft to carry out attacks against sea opponents. Attacking naval battles using airplanes will greatly benefit our comrades, because in this case, in naval battles, it is not necessary to always confront the ship with an opponent who poses a very high risk. Operational readiness is very important, there are readiness in building operational readiness for naval defense through budget fulfillment, utilization of existing resources, procurement and naval modernization by paying attention to Life Cycle Cost, and interoperability while still paying attention to paradigm shifts in naval capability. It is useful to support combat readiness that is the condition of the Indonesian Navy's defense equipment and its constituent units, resources and personnel, weapon systems and other military technology equipment in a condition that is ready to carry out military operations in an unspecified time, or function consistent with the purpose for which the defense equipment is organized or designed. , the management of resources and training personnel in preparation for combat in the face of the threat of modern warfare in a state of constant combat readiness.

At this time, training in Anti-Submarine Warfare conducted by Indonesian Navy's Helicopter is still limited to carrying out flight procedures, communication procedures with the $\mathrm{KRI}$ and the command line, because Helicopters have sensors, weapons and command that need to be upgraded and The personnel also have underwater warfare capabilities that need to be upgraded. The question in this research is whether the Indonesian Navy's military strength, especially helicopters, has been able to overcome and anticipate threats and challenges to national maritime security. What is the actual condition of the capability in ASW (Anti Submarine Warfare) at this time when faced with the development of threats from the modern generation of warfare, faced with developments in science and technology, and faced with the strategy of building the operational strength of the Indonesian Navy in 
responding to challenges and anticipating threats to the sovereignty of the Republic of Indonesia in the future.

\section{MATERIAL AND METHOD \\ 2.1 Literature Review}

In conducting current research, there are several relevant studies in the form of theories or findings in supporting problem solving. Researchers have conducted from either similar or different object, subject and approach methods used. This research identifies or studies the current level of Helicopter capability by providing a concrete threat benchmark basis, as well as analyzing technology forecasting and technological requirements that must be had in increasing operational readiness in the face of ASW (Anti Submarine Warfare).

\subsection{Strategic Management Concepts}

Strategic management can be defined as the art and science of formulating, implementing, and evaluating cross-functional decisions that enable an organization to achieve its goals. The term strategic management is synonymous with the term strategic planning more often used in the business world, while the former is often used in academia (David, 2011). Therefore, strategic management emphasizes monitoring and evaluating external opportunities and threats by considering the strengths and weaknesses of the company (Wheelen \& Hunger, 2012). Strategic management is a set of managerial decisions and actions that determine the long-term performance of a company. This includes environmental scanning (both external and internal), strategy formulation (strategic or long-term planning), strategy implementation, and evaluation and control.

\subsection{Operational Readiness}

The operational readiness of the navy is readiness in building operational readiness for naval defense through budget fulfillment, utilization of existing resources, procurement and naval modernization by paying attention to Life Cycle Cost, and interoperability while still paying attention to the paradigm shift in naval capability in the 21st century. will determine current technology adoption (FICCI and KOAN, 2018). Military capability is the ability to achieve specified war objectives, for example winning battles or wars or destroying targets, which in broad terms cannot be easily quantified (Department of Defense, 2010)

\subsection{Concept of Technology Management with Technometrics}

Mastery of technology is one of the most important parts of the "Technology Management" discipline, and represents a process that must be managed in a systematic approach from start to finish. Narin et.al (1997) suggest that there is a continuum that extends from a variety of basic scientific research writing, through research and applied technology. The most active areas of hightech growth are often very knowledge-intensive areas. Mackenzie and Wacjman (1985) suggest that technology is more than a product of scientific activity. Technology includes important normative, social, political, and ethical aspects, among others. As such, technology includes what is made and how things are made. In turn, the social and economic contexts are shaped by the technology that is produced and used. And through technology humans have acquired a strong ability to transform their natural environment locally, regionally and globally. The degree of sophistication for each technology component is based on the Technology Readiness Level of the Department of Defense (DoD) in the Defense Acquisition Guidebook 2010, according to the following table:

Table 1. Technology Readiness Level of DoD

\begin{tabular}{|c|l|}
\hline score & \multicolumn{1}{|c|}{ TRL } \\
\hline 1 & Basic principles observed and reported) \\
\hline 2 & Technology concept and/or application formulated \\
\hline 3 & $\begin{array}{l}\text { Analytical and experimental critical function and/or } \\
\text { characteristic proof of concept }\end{array}$ \\
\hline 4 & $\begin{array}{l}\text { Component and/or breadboard validation in } \\
\text { laboratory environment }\end{array}$ \\
\hline 5 & $\begin{array}{l}\text { Component and/or breadboard validation in } \\
\text { relevant environment }\end{array}$ \\
\hline 6 & $\begin{array}{l}\text { System/subsystem model or prototype } \\
\text { demonstration in a relevant environment }\end{array}$ \\
\hline 8 & $\begin{array}{l}\text { System prototype demonstration in an operational } \\
\text { environment } \\
\text { Actual system completed and qualified through test } \\
\text { and demonstration }\end{array}$ \\
\hline 9 & $\begin{array}{l}\text { Actual system proven through successful mission } \\
\text { operations) }\end{array}$ \\
\hline
\end{tabular}

There are four technology components: (1) humanware; (2) infoware; (3) orgaware; and (4) technoware (Sharif, 1993). The four components interact dynamically to determine the level of mastery of technology. In principle, there are four levels of mastery of technology, starting from the lowest being operative ability, aquisitive ability, supportive ability, and innovative ability. According to UNESCAP (United Nation Economic and Social Commission for Asia and the Pacific) in Pradana (2011), technology is a combination of 4 basic components, namely technoware, humanware, inforware, and organware (THIO) which interact with one another in a transformation process.

The contribution value of each technology component item is calculated using the input value of the sophistication level limit and the state of the art rating, using the following formula:

a. State of the art for item $\mathbf{i}$ from technoware :

$$
\text { sт. }-1 / 10 \sum_{k}\left(\frac{\mu v}{v i}\right)
$$

b. State of the art for item $\mathbf{j}$ of humanware :

$$
s=110 \sum_{1}\left(\frac{h m}{m}\right)
$$

c. State of the art for infoware : 


$$
\text { Si }-1 / 70 \sum_{m}\left(\frac{k w}{m f}\right)
$$

d. State of the art for orgaware

$$
\text { so }-1110 \sum_{n}\left(\frac{a i}{m}\right)
$$

Contribution of each Technology Component (component contribution). Based on the limits for the level of sophistication and the state-of-the-art rating above, the contribution of each technology component can be calculated based on the following equation:

$$
\begin{aligned}
\mathrm{Ti} & =1 / 9[\mathrm{LTi}+\mathrm{STi}(\mathrm{UTi}-\mathrm{LTi})] \\
\mathrm{Hj} & =1 / 9[\mathrm{LHj}+\mathrm{SHj}(\mathrm{UHj}-\mathrm{LHj})] \\
\mathrm{I} & =1 / 9[\mathrm{LI}+\mathrm{SI}(\mathrm{UI}-\mathrm{LI})] \\
\mathrm{O} & =1 / 9[\mathrm{LO}+\mathrm{SO}(\mathrm{UO}-\mathrm{LO})]
\end{aligned}
$$

To achieve the total contribution of all items, the values of $\mathrm{Ti}$ and $\mathrm{Hj}$ must be aggregated using appropriate weights based on the following formula :

$$
\begin{aligned}
& \mathrm{T}=\frac{\sum u i T i}{\sum u i} \\
& \mathrm{H}=\frac{\sum v j H j}{\sum v j} .
\end{aligned}
$$

Ui refers to the technoware investment cost for item i and $\mathrm{Vj}$ refers to the total labor for category $\mathrm{j}$

Technology Contribution Coefficient (TCC) can be calculated using equation (1). Since the values 0 $<\mathrm{T}, \mathrm{H}, \mathrm{I}, \mathrm{O}<1$ and $\beta \mathrm{t}+\beta \mathrm{h}+\beta \mathrm{i}+\beta \mathrm{o}=1$ (after normalizing), the maximum value of TCC is equal to one. The TCC rating scale and the level of the technology contribution coefficient can be determined based on the following table:

Table 2. TCC Rating Scale and Value Level

\begin{tabular}{|c|c|}
\hline Score TCC & Value Level \\
\hline 0,1 & Very bad \\
\hline 0,3 & Bad \\
\hline 0,5 & Moderate \\
\hline 0,7 & good \\
\hline 0,9 & Very good \\
\hline 1,0 & Reaching state of the art \\
\hline
\end{tabular}

The technometry will be used to calculate the Heli's current readiness level, so as to determine strategic steps to increase operational readiness.

\subsection{Analytical Hierarchy Proces (AHP) concept}

The Analytic Hierarchy Process (AHP) is a theory developed by Thomas Saaty for measuring intangible factors through paired comparisons using judgments from a 1 to 9 fundamental scale and resulting in priorities for the factors. It can be applied to both tangibles and intangibles and is used for decision making by structuring a hierarchical model with a goal, criteria (sub-criteria), and alternatives then making pairwise comparison judgments about the dominance of groups of elements in a level below with respect to the element from which they are connected in the level above. In the end the priorities of all the elements are synthesized to rank the alternatives. These simple hierarchies can be extended to multi-level decision models with hierarchies of benefits, opportunities, costs and risks.

The AHP has been applied in many areas including resource allocation and conflict resolution. There are numerous intangibles that have great impact that we must first measure before we can include them as variables. What is most significant is that intangibles can only be measured through expert judgment and only relative to the goals of concern in a particular situation. In this study, AHP is used to measure the intensity or weight of each main aspect of each technology component by analyzing using pairwise comparisons of each criteria.

\section{DATA ANALYSIS AND INTERPRETATION METHOD}

Ability in Anti-Submarine Warfare by Indonesian Navy Helicopters in supporting the Operational Readiness concept is defined as an element that has operational readiness in accordance with its main task as Anti Submarine Helicopters in carrying out operational tasks by considering the readiness of personnel, platforms (engines and fuselage), sewaco. (sensors, weapons, command) and logistics. The first step is to analyze the assessment of technology components and operational stages and determine benchmarks so that research gaps can be identified. The next step is to conduct an analysis using technometrics on the status of technology, technological capabilities, technology content, and technology requirements. The results of this analysis are used to determine strategic steps in increasing the ASW (Anti Submarine Warfare) capability of Indonesian Navy helicopters on aspects of human resource readiness and readiness (platform and sewaco). 


\subsection{The stages of readiness}

Helicopter operations towards Operational Ready served on the following diagram below:

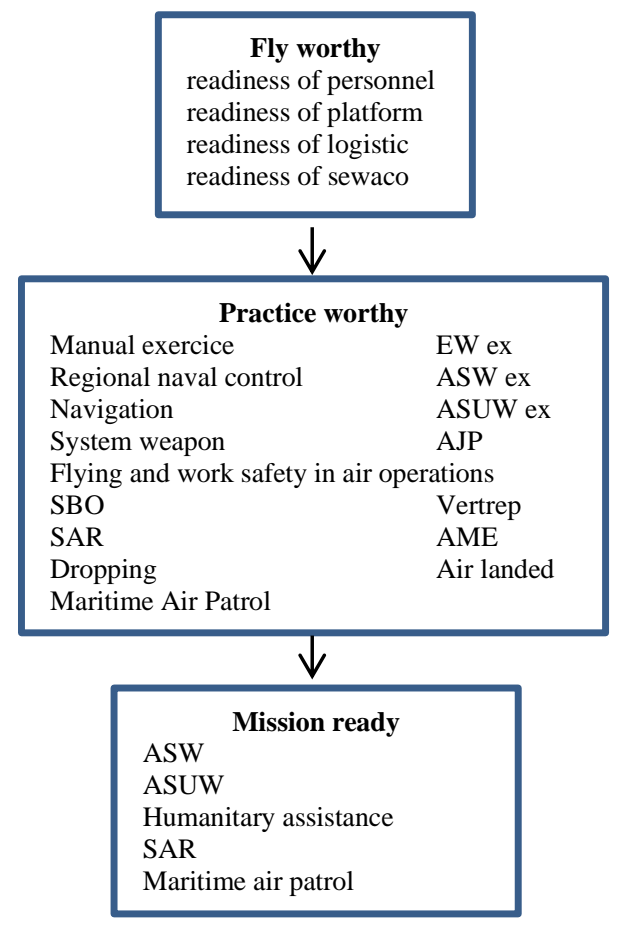

Figure 1. Helicopter Operations

\subsection{Benchmarking of potential threats}

Based on previous research, a thesis with the title strategy to increase the operational capability of the KRI in Koarmada II in supporting the operational ready force concept of the Indonesian Navy, author Harun Bekti ariyoko, STTAL - Surabaya. Based on the background of the development of threats, the State can be used as a benchmark for the direction of threats obtained through interviews with experts. Benchmarck Can be analyzed by several approaches.

a. Benchmark countries increase the intensity of safeguarding the waters of the ZEE which are claimed to be part of their country's sovereign sea area.

b. The benchmark country has significant trade competition, and there is no reciprocal advantage.

c. Benchmark countries have high morale in securing the territory of their country.

Then the determination of the direction of threats based on the criteria approach with the status of defense technology and technology capabilities, border problems, trade relations, the history of war with a country that has a strong military power, the direction of future threats is predicted to come from Vietnam.

\subsection{Analysis of the Technology Status Indonesian Navy's Anti-Submarine Helicopters}

The type of helicopter that was carried out on the technology status assessment is AS565 MBe
Panther. Technology status assessment is one of the important steps in formulating technology transfer policies and developing technology selection strategies, so that technology development and technological competitiveness advantages can be achieved appropriately, quickly and efficiently in order to obtain an increase in its operational capabilities. Through the Technology Status assessment approach (ESCAP 1988), qualitative and quantitative identification and studies can be carried out. There are three indicators to show the status of technology in this approach : (technological gap), (technological change) and (technology life cycle). In this research, it is limited to only technology gap approach.

Table 3. Indicators to Show the Technology Status

\begin{tabular}{|c|c|c|c|c|c|}
\hline no & Technology & Indonesia & ability & Vietnam & Ability \\
\hline 1 & Sensor & $\begin{array}{l}\text { Raytheon } \\
\text { Whitehead A244/S. } \\
\text { DS-100 HELRAS }\end{array}$ & $60 \mathrm{~nm}$ & $\begin{array}{l}\text { planar E-801M OKO } \\
\text { MAD dipping sonar }\end{array}$ & $40 \mathrm{~nm}$ \\
\hline 2 & Weapon & $\begin{array}{l}\text { Rockets : } 68 \mathrm{~mm} \text { or } 70 \\
\text { mm unguided rocket } \\
\text { Missiles : } \\
\text { - Mistral air to air Missile } \\
\text { - As } 15 \mathrm{TT} \text { anti surface } \\
\text { missile } \\
\text { - HOT anti-tank missile } \\
\text { - Mk } 46 \text { white head - } \\
\text { ASW torpedoes }\end{array}$ & - & $\begin{array}{l}\text { Torpedoes: } \\
\text { AT-1M } \\
\text { VTT-1 } \\
\text { UMGT-1 orlan } \\
\text { APN-2 yastreb } \\
\text { 36 RGD-NM } \\
\text { RGB-NM-1 } \\
\text { 7.62 machine gun } \\
\text { 30mm cannon 2A42 } \\
\end{array}$ & $\begin{array}{l}1 \\
1 \\
1 \\
1 \\
1 \\
1 \\
1 \\
1 \\
1 \\
1\end{array}$ \\
\hline 3 & Radio & $\begin{array}{l}\text { V/UHF } \\
\text { ICS } \\
\text { PIA } \\
\text { AM/FM } \\
\end{array}$ & 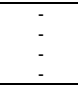 & $\begin{array}{l}\text { V/UHF } \\
\text { ICS } \\
\text { PIA } \\
\text { AM/FM } \\
\end{array}$ & 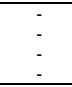 \\
\hline 4 & Platform & $\begin{array}{l}\text { Capacity } \\
\text { Length } \\
\text { Rotor Diameter } \\
\text { Height } \\
\text { Empty Weight } \\
\text { Gross Weight } \\
\text { Powerplant } \\
\text { Maximum speed } \\
\end{array}$ & $\begin{array}{l}10 \\
13.68 \mathrm{~m} \\
11.94 \mathrm{~m} \\
3.97 \mathrm{~m} \\
2380 \mathrm{~kg} \\
4300 \mathrm{~kg} \\
852 \mathrm{hp} \\
190 \mathrm{mph} \\
\end{array}$ & $\begin{array}{l}\text { Capacity } \\
\text { Length } \\
\text { Rotor Diameter } \\
\text { Height } \\
\text { Empty Weight } \\
\text { Gross Weight } \\
\text { Powerplant } \\
\text { Maximum speed }\end{array}$ & $\begin{array}{l}16 \\
11.3 \mathrm{~m} \\
15.8 \mathrm{~m} \\
5.5 \mathrm{~m} \\
6500 \mathrm{~kg} \\
11000 \mathrm{~kg} \\
2230 \mathrm{hp} \\
127 \mathrm{mph}\end{array}$ \\
\hline 5 & Number & Panther & 11 & Kamov-27 & 6 \\
\hline
\end{tabular}

Globally Panther helicopters are better on platforms and sensors, but the biggest gap is in weaponry capabilities, where Vietnam is superior because each helicopter is equipped with weapons, The number of Indonesian helicopters is more than vietnam.

Table 4. Technology Status

\begin{tabular}{|l|l|}
\hline \multicolumn{2}{|c|}{ Technology status } \\
\hline \multicolumn{1}{|c|}{ strengh } & \multicolumn{1}{c|}{ explanation } \\
\hline $\begin{array}{l}\text { Technology gap } \\
\text { Dubstitution of technology } \\
\text { Analysis of technology } \\
\text { innovation }\end{array}$ & $\begin{array}{l}\text { Indonesia's technology is parallel to Vietnam } \\
\text { Revitalization } \\
\text { According to the type of KRI } \\
\text { Independence in procuring helicopters }\end{array}$ \\
\hline \multicolumn{1}{|c|}{ weakness } & \multicolumn{1}{c|}{ explanation } \\
\hline Technology gap & $\begin{array}{l}\text { The Indonesian Navy's anti-submarine helicopter } \\
\text { weaponry is below Vietnam's weaponry capability } \\
\text { Weapon revitalization } \\
\text { Substitution technology } \\
\text { Budget analysis } \\
\text { Analysis technology } \\
\text { innovation }\end{array}$ \\
independence in the procurement of weapons
\end{tabular}

\subsubsection{Development stage of human resources in anti-submarine helicopters}

The human resources development stage is a holistic effort by considering the dynamics of the strategic environment and the demands of the assignment in the face of real conditions and budget availability, resulting in a priority, stages of human resource development that can change dynamically according to the level of achievement at the previous stage and developments in field. 
Table 5. Development stage of human resources in anti-submarine helicopters

\begin{tabular}{|l|c|c|}
\hline \multicolumn{3}{|c|}{ Degree of technical sophistication of the device } \\
\hline & Indonesia & Vietnam \\
\hline Maritime intelligence capabilities & 7 & 9 \\
\hline Defense ability & 7 & 9 \\
\hline Cooperative engagement capability & 7 & 9 \\
\hline
\end{tabular}

\subsubsection{Information Development Stage in Anti-} Submarine Helicopters

Military communication technology is critical to the success of an operation. The development of information and communication technology demands the implementation of an increasingly complex operation degree where the guarantee of smooth, robust, secure and trustworthy communication. Development of information tools based on the criteria for assessing the strength and capabilities of the two countries:

Table 6. Development Stage in Anti- Submarine Helicopters

\begin{tabular}{|l|c|c|}
\hline \multicolumn{2}{|c|}{ Degree of technical sophistication of the device } \\
\hline & Indonesia & Vietnam \\
\hline Maritime intelligence capabilities & 8 & 9 \\
\hline Defense ability & 8 & 9 \\
\hline Cooperative engagement capability & 8 & 9 \\
\hline
\end{tabular}

\subsubsection{The development stage of the organizational}

It is hoped that the Indonesian Navy organization will become an organization capable of ensuring the implementation of the development and operation aspects of defense equipment, especially in anti-submarine helicopters that are capable of facing threats in different trouble spots.

Table 7. Development Stage of the Organizational

\begin{tabular}{|l|c|c|}
\hline \multicolumn{2}{|c|}{ Degree of technical sophistication of the device } \\
\hline & Indonesia & Vietnam \\
\hline Maritime intelligence capabilities & 8 & 9 \\
\hline Defense ability & 8 & 9 \\
\hline Cooperative engagement capability & 8 & 9 \\
\hline
\end{tabular}

From the results of the analysis of technological capabilities in Indonesia and Vietnam, it can be concluded that the development of human resources in Indonesia in using technical tools has the highest gap compared to the development of information tools and the development of organizational instruments. This is because the factors in carrying out the exercises are still using many assumptions, in any implementation of HR training that is owned has never carried out in real time and is in accordance with real conditions.

The results of the analysis of the calculation of technological capabilities are presented in the form of table data below :

Table 8. Analysis of the calculation of technological capabilities

\begin{tabular}{|l|c|c|c|}
\hline Analysis factor & Indonesia & Vietnam & Gap \\
\hline HR development & 21 & 27 & 6 \\
\hline Information development & 24 & 27 & 3 \\
\hline $\begin{array}{l}\text { Organizational } \\
\text { development }\end{array}$ & 24 & 27 & 3 \\
\hline
\end{tabular}

The results of the analysis of technological capabilities, if based on information and data, will provide an overview of the weaknesses and strengths of the capabilities of anti-submarine helicopter technology. Supported by the ability to develop human resources in manning the ever-developing technical equipment.

\subsection{Analysis of Component Content Analysis of anti-submarine helicopter technology}

Estimation of the degree of sophistication of the technology component is carried out by assessing the actual conditions of the technology used. Assessment refers to the UNESCAP (1989) assessment procedure, with the recommended scoring method for all four technology components.

The degree of sophistication for each technology component is based on the Technology Readiness Level of the Department of Defense.

Table 9. Degree of Sophistication for Each Technology Component

The level of sophistication of technological components

\begin{tabular}{|c|c|c|c|c|}
\hline Technoware & Humanware & Infoware & Orgaware & score \\
\hline Manual tools & Able to use & $\begin{array}{l}\text { Able to provide } \\
\text { and manage } \\
\text { data }\end{array}$ & $\begin{array}{l}\text { Small } \\
\text { organization }\end{array}$ & $\begin{array}{l}1 \\
2 \\
3\end{array}$ \\
\hline $\begin{array}{l}\text { Mechanic } \\
\text { tools }\end{array}$ & Able to install & $\begin{array}{l}\text { Able to provide } \\
\text { and manage } \\
\text { data }\end{array}$ & $\begin{array}{l}\text { The organization } \\
\text { begins } \\
\text { collaborate }\end{array}$ & $\begin{array}{l}2 \\
3 \\
4 \\
\end{array}$ \\
\hline $\begin{array}{l}\text { General } \\
\text { function } \\
\text { equipment }\end{array}$ & Able to care & $\begin{array}{l}\text { Able to provide } \\
\text { and manage } \\
\text { data }\end{array}$ & $\begin{array}{l}\text { Organizations } \\
\text { start to have } \\
\text { networks }\end{array}$ & $\begin{array}{l}3 \\
4 \\
5\end{array}$ \\
\hline $\begin{array}{l}\text { Special } \\
\text { function } \\
\text { equipment }\end{array}$ & Able to fix & $\begin{array}{l}\text { Able to provide } \\
\text { and manage } \\
\text { data }\end{array}$ & $\begin{array}{l}\text { The organization } \\
\text { have a network, } \\
\text { collaborations, } \\
\text { continued to } \\
\text { grow }\end{array}$ & $\begin{array}{l}4 \\
5 \\
6\end{array}$ \\
\hline $\begin{array}{l}\text { Automatic } \\
\text { equipment }\end{array}$ & $\begin{array}{ll}\begin{array}{l}\text { Able } \\
\text { develop }\end{array} & \text { to } \\
\end{array}$ & $\begin{array}{l}\text { Able to provide } \\
\text { and analyze } \\
\text { data } \\
\text { information }\end{array}$ & $\begin{array}{l}\text { Organization has } \\
\text { a collaborative } \\
\text { network and } \\
\text { continues to } \\
\text { grow }\end{array}$ & $\begin{array}{l}5 \\
6 \\
7\end{array}$ \\
\hline $\begin{array}{l}\text { Computerized } \\
\text { equipment }\end{array}$ & $\begin{array}{ll}\text { Able } & \text { to } \\
\text { innovate }\end{array}$ & $\begin{array}{l}\text { Able to } \\
\text { provide, } \\
\text { analyze and } \\
\text { process data }\end{array}$ & $\begin{array}{l}\text { Organizations } \\
\text { are able to } \\
\text { develop and } \\
\text { compete }\end{array}$ & $\begin{array}{l}6 \\
7 \\
8\end{array}$ \\
\hline $\begin{array}{l}\text { Integrated } \\
\text { equipment } \\
\text { and facilities }\end{array}$ & $\begin{array}{l}\text { Able to do } \\
\text { their own } \\
\text { innovation }\end{array}$ & $\begin{array}{l}\text { Able to } \\
\text { provide, } \\
\text { analyze, } \\
\text { process and } \\
\text { manage data }\end{array}$ & $\begin{array}{l}\text { the organization } \\
\text { develops, is able } \\
\text { to compete and } \\
\text { is able to } \\
\text { become a leader } \\
\text { and establish } \\
\text { international } \\
\text { relations }\end{array}$ & $\begin{array}{l}7 \\
8 \\
9\end{array}$ \\
\hline
\end{tabular}


Technology components have their own unique identity but in the implementation of technological activities all of these components interact with one another. The interaction of each technology component will show different contributions according to time, place, and actors in achieving the goal.

\subsubsection{Transformation Stages in an Operational Process on an Anti-Submarine Helicopter}

To describe the transformation process in preparing anti-submarine helicopters for operational readiness, it can be simplified into important stages as follows:

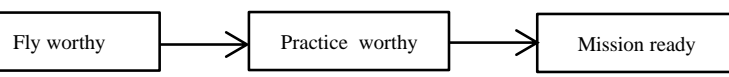

Figure 2. Transformation Stages

\subsubsection{Degree of sophisticated technology components in anti-submarine helicopters}

The degree of sophistication of the technology component is determined by giving a scale score ranging from 1-9. The estimation results will provide the upper limit / UL and lower limit / LL for each technology component.

Table 10. Degree of Sophisticated Technology

\begin{tabular}{|l|c|c|c|c|}
\hline \multirow{2}{*}{ Technology Components } & \multicolumn{3}{|c|}{ indonesia } & \multicolumn{3}{|c|}{ vietnam } \\
\cline { 2 - 5 } & UL & LL & UL & LL \\
\hline Technoware & & & & \\
Fly worthy & & & & \\
readiness of personnel & 7 & 9 & 7 & 9 \\
readiness of platform & 7 & 9 & 7 & 9 \\
readiness of logistic & 6 & 8 & 7 & 9 \\
readiness of sewaco & 6 & 9 & 7 & 9 \\
Practice worthy & & & & \\
Manual exercice & 7 & 9 & 7 & 9 \\
EW ex & 7 & 9 & 7 & 9 \\
Regional naval control & 7 & 9 & 7 & 9 \\
ASW ex & 7 & 9 & 7 & 9 \\
Navigation & 7 & 9 & 7 & 9 \\
ASUW ex & 7 & 9 & 7 & 9 \\
System weapon & 7 & 9 & 7 & 9 \\
AJP & 7 & 9 & 7 & 9 \\
Flying and work safety in air operations & 7 & 9 & 7 & 9 \\
SBO & 7 & 9 & 7 & 9 \\
Vertrep & 7 & 9 & 7 & 9 \\
SAR & 7 & 9 & 7 & 9 \\
AME & 7 & 9 & 7 & 9 \\
Dropping & 7 & 9 & 7 & 9 \\
Air landed & 7 & 9 & 7 & 9 \\
Maritime Air Patrol & 7 & 9 & 7 & 9 \\
Mission ready & & & & \\
ASW & 7 & 9 & 7 & 9 \\
ASUW & 7 & 9 & 7 & 9 \\
Humanitary assistance & 7 & 9 & 7 & 9 \\
SAR & 7 & 9 & 7 & 9 \\
Maritime air patrol & 7 & 9 & 7 & 9 \\
Humanware & & & & \\
Pilot & 7 & 9 & 7 & 9 \\
Co-pilot & 7 & 9 & 7 & 9 \\
Crew & 7 & 9 & 7 & 9 \\
Infoware & 7 & 9 & 7 & 9 \\
Orgaware & 7 & 9 & 7 & 9 \\
\hline
\end{tabular}

\subsubsection{State of the Art (SOTA) Calculation}

The state of the art of each technology component is scored based on the assessment criteria for the complexity of the technology component in the anti-submarine helicopter determined by the expert according to the table.

Table 11. State of The Art (SOTA) Calculation

\begin{tabular}{|l|l|l|l|l|}
\hline \multirow{2}{*}{\multicolumn{1}{|c|}{ Criteria }} & \multicolumn{2}{|c|}{ Indonesia } & \multicolumn{2}{c|}{ Vietnam } \\
\cline { 2 - 5 } & $\begin{array}{c}\text { Criteria } \\
\text { score }\end{array}$ & $\begin{array}{c}\text { sco } \\
\text { re }\end{array}$ & $\begin{array}{c}\text { Criteria } \\
\text { score }\end{array}$ & $\begin{array}{c}\text { sco } \\
\text { re }\end{array}$ \\
\hline Fly worthy & Qualitative & 8 & Quantitative & 9 \\
readiness of personnel & Qualitative & 8 & Quantitative & 9 \\
readiness of platform & Qualitative & 8 & Quantitative & 9 \\
readiness of logistic & Qualitative & 8 & Quantitative & 9 \\
readiness of sewaco & & & & \\
Practice worthy & & & &
\end{tabular}

\begin{tabular}{|l|l|l|l|l|}
\hline Manual exercice & Quantitative & 8 & Quantitative & 9 \\
EW ex & Quantitative & 8 & Quantitative & 9 \\
Regional naval control & Quantitative & 8 & Quantitative & 9 \\
ASW ex & Quantitative & 7 & Quantitative & 9 \\
Navigation & Quantitative & 8 & Quantitative & 9 \\
ASUW ex & Quantitative & 7 & Quantitative & 9 \\
System weapon & Quantitative & 8 & Quantitative & 9 \\
AJP & Quantitative & 9 & Quantitative & 9 \\
Flying and work safety in air operations & Quantitative & 9 & Quantitative & 9 \\
SBO & Quantitative & 8 & Quantitative & 9 \\
Vertrep & Quantitative & 8 & Quantitative & 9 \\
SAR & Quantitative & 9 & Quantitative & 9 \\
AME & Quantitative & 8 & Quantitative & 9 \\
Dropping & Quantitative & 9 & Quantitative & 9 \\
Air landed & Quantitative & 9 & Quantitative & 9 \\
Maritime Air Patrol & Quantitative & 9 & Quantitative & 9 \\
Mission ready & & & \\
ASW & Quantitative & 7 & Quantitative & 9 \\
ASUW & Quantitative & 8 & Quantitative & 9 \\
Humanitary assistance & Quantitative & 8 & Quantitative & 9 \\
SAR & Quantitative & 9 & Quantitative & 9 \\
Maritime air patrol & Quantitative & 9 & Quantitative & 9 \\
\hline
\end{tabular}

\subsubsection{Calculation Technology Coefficient Contribution (TCC)}

Table 12. Calculation Technology Coefficient Contribution (TCC)

\begin{tabular}{|c|c|c|c|c|c|c|c|}
\hline \multirow{3}{*}{$\begin{array}{l}\text { Technology } \\
\text { Components }\end{array}$} & \multicolumn{6}{|c|}{ TCC } & \multirow{3}{*}{ gap } \\
\hline & \multicolumn{3}{|c|}{ indonesia } & \multicolumn{3}{|c|}{ vietnam } & \\
\hline & $\begin{array}{c}\text { Contribut } \\
\text { ion } \\
\text { Value }\end{array}$ & $\begin{array}{l}\text { Inten } \\
\text { city }\end{array}$ & TCC & $\begin{array}{l}\text { Contribut } \\
\text { ion Value }\end{array}$ & $\begin{array}{l}\text { Inten } \\
\text { city }\end{array}$ & TCC & \\
\hline Technoware & 34,2 & 0,19 & 6,5 & 35,12 & 0,19 & 6,67 & 0,17 \\
\hline Humanware & 29,69 & 0,15 & 4,45 & 33,05 & 0,15 & 4,96 & 0,50 \\
\hline Infoware & 23,60 & 0,3 & 7,08 & 24,39 & 0,3 & 7,32 & 0,24 \\
\hline Orgaware & 31,36 & 0,33 & 10,35 & 32,22 & 0,33 & 10,63 & 0,29 \\
\hline
\end{tabular}

\subsection{Technology Needs to support the Operational Readiness}

Technology needs to increase capabilities in the operational and direction fields according to general, specific, and integrated technology needs:

a. General technology : Navigation Radar, Implementing transfer of technology with the longterm goal of creating its own radar and weapons.

b. Specific technology : fire control radar, torpedo weapon, ASM, machine gun; research and development and engineering of radar, sonar, CIWS and ASM equipment.

c. Intregated technology : Integrated Combat System updated, Self-produced Radar, Sonar, CIWS, ASM and Integrated Combat System tools.

\section{RESULT AND DISCUSSION}

The result from the data analysis and calculation above are:

a. Strategy 1. Implement budget efficiency and effectiveness for increasing the number of weapons and completing the sewaco system.

b. Strategy 2. Improve the pattern of logistics development in maintenance and maintenance to increase the pattern of degrees in support of presence at sea at all times

c. Strategy 3. Increase the use of domestically produced defense equipment, the results of research, 
development and technology engineering in accordance with the government's commitment to develop the national defense industry.

d. Strategy 4. Increasing the capability and professionalism of equipment manning including materials, platforms, weapons, radar, communications, and facilities and infrastructure.

e. Strategy 5. Optimizing operational and procurement, repair and maintenance budgets to prepare and improve helicopter operations and combat capabilities

f. Strategy 6. Increasing the intensity of cooperation for operations and training as well as supporting naval diplomacy.

\section{CONCLUSION}

By identifying capabilities through the Technology Status Analysis, the capabilities between Indonesian Navy helicopters and Vietnamese helicopters are almost equal, but long distances are within the capabilities of technoware in procuring missiles independently. In the analysis of technological capabilities, there is a huge gap in HR development. Meanwhile, in the analysis of the content of technology contributions, there is a big gap in the humanware component. This shows that the capabilities of the helicopter in terms of infoware and orgaware components are not that far away, in terms of technoware components there is a large gap in the capabilities of the weapons components owned, besides that there is also a gap in the humanware component. So it is necessary to increase the human resource capacity of its soldiers through education and training

The results of the analysis of technological needs in the modern era, an important and urgent need to be met is the adjustment and dynamism of the Doctrine of Warfare, increasing the capability of personnel, updating and researching platforms and Radar equipment and Weapons and Communications

The formulated strategy is to increase the capability of the Soldier's human resources in supporting the readiness of helicopter combat operations in facing ASW and the strategic aspects of increasing readiness capabilities (Platform and Sewaco).

The results of the Risk Assessment analysis show that the steps that must be taken are Correction Required (need to be corrected immediately), this means that there is a need for immediate evaluation and correction in order to increase capacity through routine and directed and measured training steps that have concrete objectives.

\section{ACKNOWLEDGEMENTS}

The authors would like to thank the supervisors, commanders and staff of STTAL, the Indonesian Navy flight command and training commander, air wing 2 operational staff, the 400 air squadron commander and all colleagues who helped complete this paper. With all our humility and limited knowledge, we realize that there are still many shortcomings and are still far from perfection in writing this paper, therefore criticism and suggestions from readers really hope for improvement and can provide input for future writers, for the fix. Finally, I hope that the results of writing this paper can be useful for the development of knowledge for writers in particular and for readers in general.

\section{REFERENCE}

Department of Defence. (2010). Defence Acquisition Guidebook. USA: Department of Defence

Harun, B., (2019) Strategi peningkatan kemampuan operasi KRI di koarmada II dalam mendukung konsep Operational Ready Force TNI Angkatan Laut. Surabaya: STTAL

Mabesal,(1988). Buku Petunjuk Taktis Penerbangan TNI Angkatan Laut. Jakarta: Mabesal

Mabesal. (1989). Buku petunjuk Pengintaian Taktis Udara TNI AL. Jakarta: Mabesal.

Mabesal. (2009). Perkasal Nomor Perkasal/35/V/2009 tanggal 19 Mei 2009 tentang Pokok-Pokok Organisasi dan Prosedur Pusat Penerbangan TNI Angkatan Laut. Jakarta : Mabesal

Mabesal. (2018) Rencana Strategi Penerbangan TNI AL Tahun 2020-2024. Jakarta: Mabesal

Mabesal. (2019). Kebijakan Perencanaan TNI Angkatan Laut Tahun 2020. Jakarta: Mabesal

Puspenerbal. (2009). Penerbangan Laut Wing Buku Taktik Udara . Jakarta: Puspenerbal

Saaty, T. (1987). The analytic hierarchy process what is it and how it is used. International journal of math modelling, 167-176

Saaty,T. \& Sodenkamp, M. (2008). Making Decisions In Hierarchic And Network System. International Journal of Applied Decision Sciences, 24-79.

David, F. R. (2011). Strategic management: Concepts and Cases (14th ed.). Person Academic

United States Coast Guard, (1999). Operational Risk Management (ORM): COMDTINST 3500.3. Washington: US. Department of Transportation United States Coast Guard 